\title{
非上皮性悪性腫瘍の剝離細胞診断 筋原性肉腫の剝離細胞像
}

\author{
国立がんセンター研究所病理 \\ 山田喬 \\ 同愛記念病院外科 \\ 坦花昌彦小崎伊佐夫田林晃 \\ 県西部浜松医療センター外科*中検病理** \\ 宔人敏三郎* 土井久平炈
}

剝離細胞診の第一義的目的は, 剝離細胞の形態を判定 することにより，悪性か否かを診断することにあるが， さらにこれを進めて，その腫瘍の組織発生起源を明らか にすることが出来れば，その効用はより大きくなる19).

しかし現在剝離細胞診の対象は主として上皮性の悪性腫 瘍であり（血液リンパ系腫瘍は除いて）, 非上皮性悪性 細胞についての形態学的知見は乏しい.

その発生頻度から云っても, 非上皮性細胞由来の腫瘍 を経験することは少ないが，治療との兼ねあいから云っ ても, この腫富の形態を正しく認識することは望まし い. 一般に非上皮性悪性腫瘍は，その発生の由来が多様 であることと, 上皮性悪性細胞以上に多分化な形質発現 を示すから，その診断を細胞の形態によってのみ行なう ことはきわめて困難であることも充分推定される.

そこでわれわれはまず非上皮性覀性腫瘍を, 筋原性, 脂肪原性, 神経原性, 線維血管原性, 骨軟骨原性のそれ ぞれの肉腫に大別して, その剝離細胞の形態を整理し, そしてそれぞれの病理組織学的背景との相関を考慮しつ つ検索した。

Exfoliative cytology on malignant neoplasms of the non-epithelial origin : Cytologic morphology of myogenic sarcomas.

Takashi YAMADA

Div. of Path., Nat. Cancer Center Res. Inst.

Masahiko KAKIHANA, Isao KOSAKI, Akira TABA-

YASHI

Dept. of Surgery, Fraternity Memorial Hospital.

Binsaburo MUROHISA, Kyuhei DOI

Dept of Surgery and Path., Hamamatsu Medical Center.
たとえ頻度は少なくとも採取され細胞学的診断の対象 になりらる非上皮性悪性腫瘍の形態学的認識の基礎を現 時点で一応設定したいと思らからである. 本編では，笳 原性肉腫の剝離細胞像を平滑筋肉腫および横紋筋肉腫に 分けて検討した.

\section{症例}

対象例 11 例中, 平滑笳肉腫 7 例, 横紋筋肉腫 4 例で

表 1 筋原性肉腫症例 平滑筋肉腫症例

\begin{tabular}{|c|c|c|c|}
\hline 症例 (整理番号) & 年令, 性 & 原発部 & 採 取 法 \\
\hline 1 I.S. $(S-244-69)$ & 47. $\mathrm{m}$ & 後腹壁 & 直接塗抹 \\
\hline 2 Y.K. $(S-271-69)$ & 62. $\mathrm{m}$ & 肝門部 & " \\
\hline 3 I.A. $(S-181-72)$ & $56 . \mathrm{f}$ & 子 宮 & " \\
\hline $4 \mathrm{~K} . \mathrm{U} \cdot(6322)$ & 67. $\mathrm{m}$ & 膀 胱 & $\begin{array}{l}\text { キモトリプシン } \\
\text { 洗滌法 }\end{array}$ \\
\hline $5 \mathrm{~K} \cdot \mathrm{K} \cdot(\mathrm{C}-2389)$ & 13. $\mathrm{f}$ & 胃 & 直接塗抹 \\
\hline 6 M.Y.（不明) & 68. $\mathrm{m}$ & 胃 & 直視下洗滌法 \\
\hline $7 \mathrm{M} \cdot \mathrm{K} \cdot(\mathrm{SN}-3419)$ & $66 . \mathrm{f}$ & 鼠頸部 & 直接塗抹* \\
\hline
\end{tabular}

* 甲状腺転移巣支擦過塗抹

横紋筋肉腫症例

\begin{tabular}{|c|c|c|c|}
\hline 症例(整理番号) & 年令,性|原発部 $\mid$ & 組織型 & 採 取 法 \\
\hline 1 T.S.(6406) & 4. $\mathrm{m}$ 膀 胱 1 & Botryoid & $\begin{array}{l}\text { キモトリプ } \\
\text { シン洗滌法 }\end{array}$ \\
\hline 2 K.N.(S $-24-72)$ & 7. $\mathrm{m} \mid \begin{array}{l}\text { 左肩甲 } \\
\text { 部 }\end{array}$ & Embryonal & 直接塗抹 \\
\hline 3 S.I. (S $-52-72)$ & 71. f 卵巣* & Pleomorphic & " \\
\hline 4 M.S. $(\mathrm{S}-230-72)$ & 2. $\mathrm{m} \mid \begin{array}{l}\text { 右外聴 } \\
\mid\end{array}$ & anaplastic & "I \\
\hline
\end{tabular}




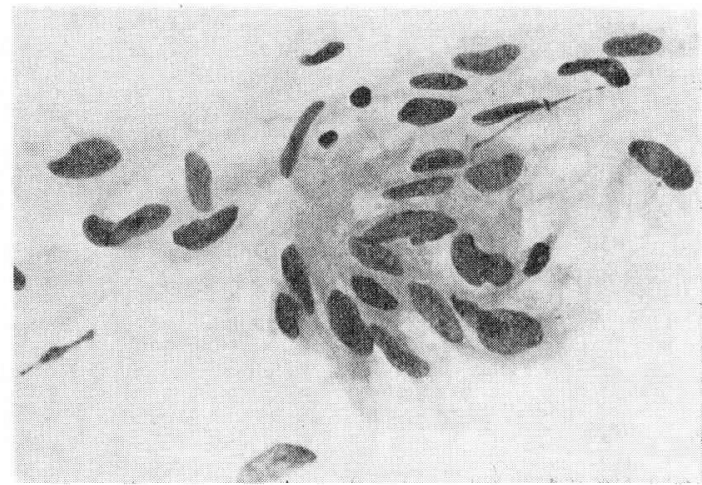

図 1 症例 1 , 分化型平滑筋肉腫剝離細胞像 $(\times 400)$

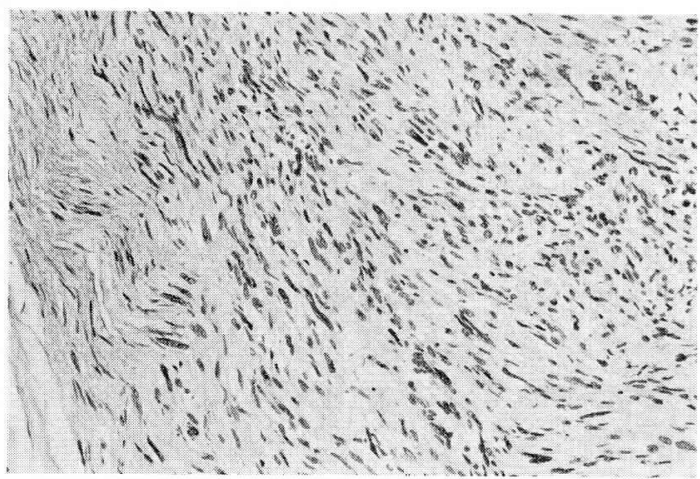

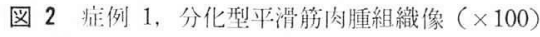

あり，前者の 2 例（膀胱 1, 胃 1）上後者の1例（膀胱） はキモトリプシン1,7) あるいは直視下洗滌法により臨床 的に細胞を採取したものである.他の8例は手術材料あ るいは部検材料から直接塗抹することにより細胞を採取 した（表1）.

採取細胞は $1: 1$ エーテル，アルコール湿潤固定，へ マトキシリン，エオジンあるいはパパニコロ染色を行な い検索した。

\section{剝離細胞像と組織学的背景}

平滑筋肉腫：いずれも分化の程度の差こそあれ，線維 状の筋肉腫細胞が剝離した。直接叙抹の分化型の例で は，図 1 に示すごとく，細胞質の中央に位置した細長い 核と線と線維状構造が綐に走る紡鍾ないし線維状の細胞 質よりなる細胞より構成された細胞群である. 細胞相互 にあまり形態学的差がなく単調で，核分裂像も少ない。

一見覀性の印象を与えない。兵組織像は㘠に示すごと くよく分化した平滑筋肉腫である(症例 1)。これに対し 症例 2 では細胞の大小不同がやや強く，核分裂像も稀な らず認めた。多核細胞を混えた巨細胞，特に細長い巨細 胞が目立ち，核型は不整で，切りこみ，陥凹むみられク

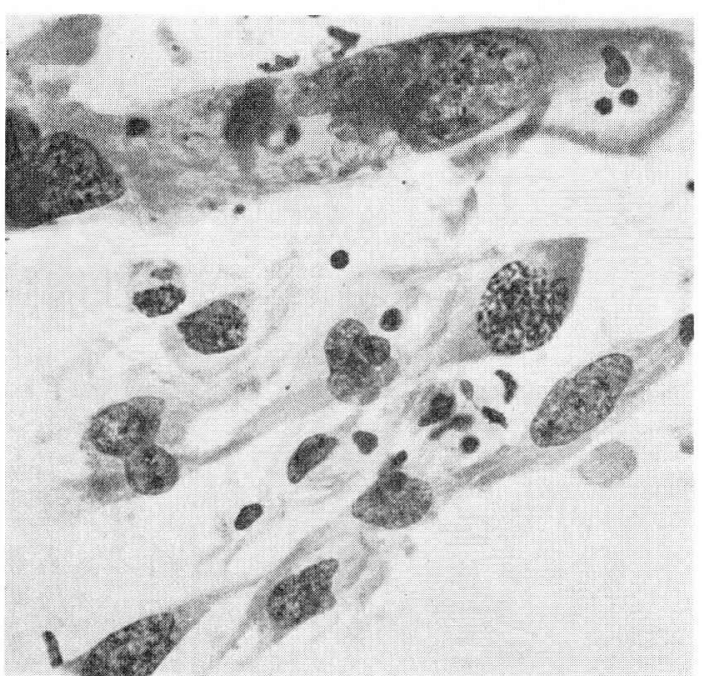

図 3 症例 2 , 平滑筋肉腫剝離細胞像 $(\times 400)$

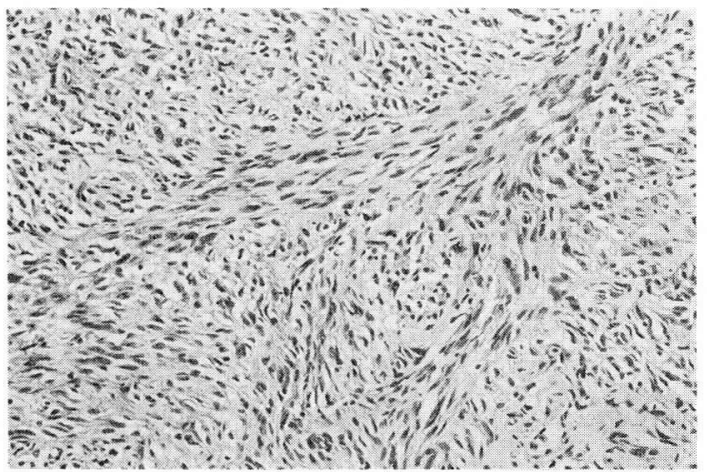

図 4 症例 2 , 組織像 $(\times 100)$

ロマチン凝集像も著明であった（図 3)。その組織像は図 4 亿示寸ごとく, 症例 1 に比較して細胞型は大きく分裂 像もやや多く認める平滑筋肉腫であった.

症例 3,7 は症例 2 上同様な分化度を示寸細胞組織像 であり, 症例 5 は症例 1 と同様な分化型の平滑筋肉腫で めった。

キモトリプシン洗被法により採取した症例 4 の䏽胱平 滑筋肉腫の細胞は, 合併した炎症性変化のために多少変 性しているが，大型な紡鍾状の異型細胞が剝離すると共 に，図 5 に示すごとき一見相互封入を思わせる細胞が発 見された。しかし相互の巻き合い法疎で，しかも核ク口 マチンは変性しているが微細であり, 核膜は薄く扁平上 皮癌細胞とは明らかに異なる。年の組織像は図 6 亿示す ごとく, 症例 2 よりさらに未分化な所見であり，短い紡 鍾状の細胞より構成される平滑筋肉腫であった。

症例 6 は巨大な胃平滑筋肉腫であり，図９亿示すごと く，その表面のごく一部が壊死となり，胃内腔と交通し， 


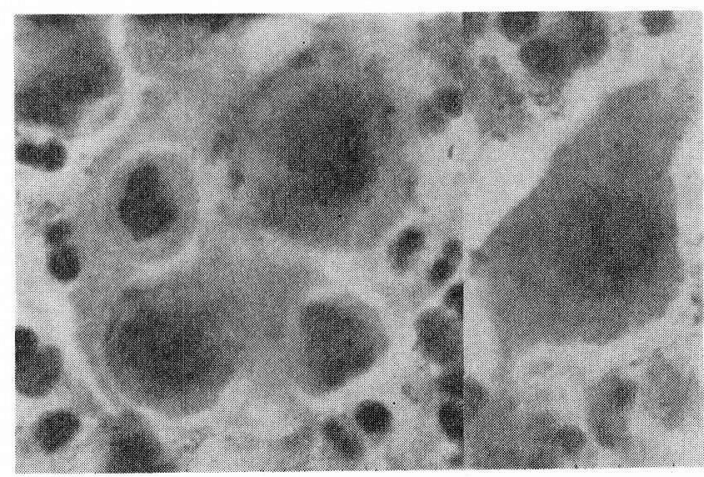

図 5 症例 4 のキモトリプシン洗湺により得られた異型細胞 $(\times 1000)$

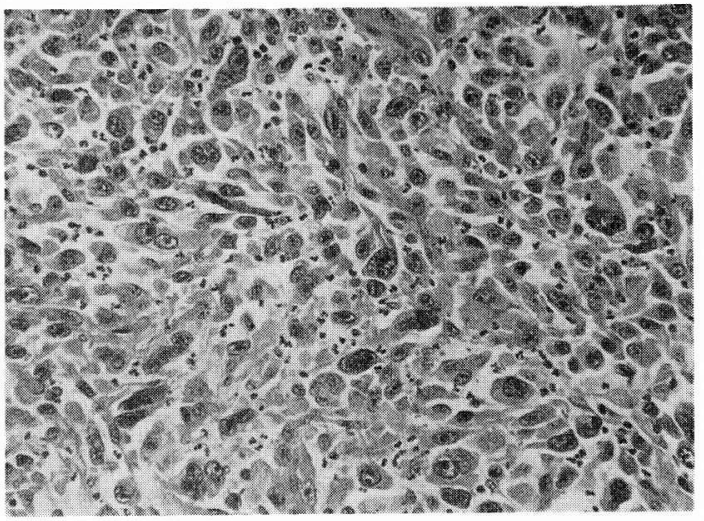

図 6 症例 4 の平滑筋肉腫組織像 $(\times 200)$

大部分は胃粘膜により被覆されていた，直視下洗滌法に より，この細い潰陽内に洗滌液を注入して採取したもの である、したがってごく少数の細胞のみしか得られなか ったが，図7，図8のごとき細胞が認められた。.多くの 細胞の形態は潰瘍部の壊死と炎症のため必ずしも明膫で はないが，しかし図 7，8 亿示すごとく，核膜泳く， なクロマチンは微練顆粒状であり，しかも細胞質は胃癌 練胞に比較すると, やや均質である. 図 8 の左下に見え るような連珠状の三核細胞は胃癌細胞にはきわめて稀で ある.全体としては紡錘状の細胞が多い。臨床的には, これらの細胞所見と, し線内視鏡所見より, 平滑筋肉腫 と術前に診断しえた例である。

以上の症例の剝離細胞を通覧すると, 平滑筋肉腫細胞 はいずれも線維状ないし紡鍾状細胞であり，その細胞の 種類は単調である。核は一般に不整形ないし卵円形であ り，核クロマチンは微細，核膜は薄いが明膫，連珠ない し不整の多核細胞がある. 細胞質は比較的均一で, 膀胱 内に剥離した細胞のごとく変性に陷ると, ガラス状に均 質となる。これらの細胞の形態は, その腫崵の分化の程 度により多少異なり, 細胞異形の著明な例は分裂像も多

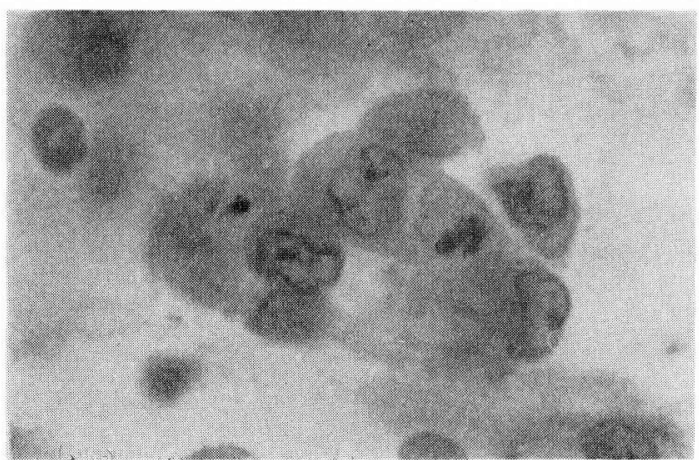

図 7 症例 6 胃直視下洗滌により得られた異型細胞 $(\times 1000)$

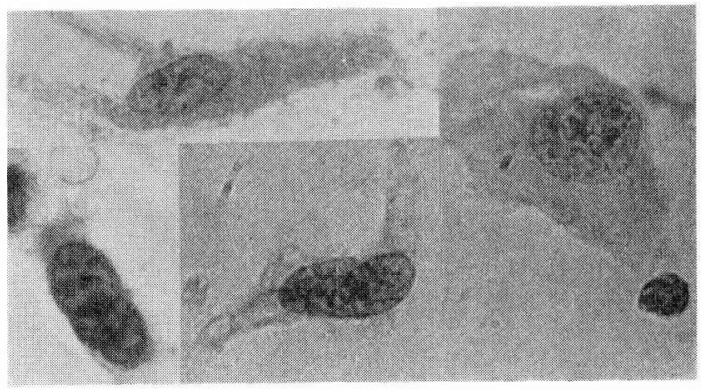

図 8 症例 6 胃直視下洗滌により得られた異型細胞 $(\times 1000)$

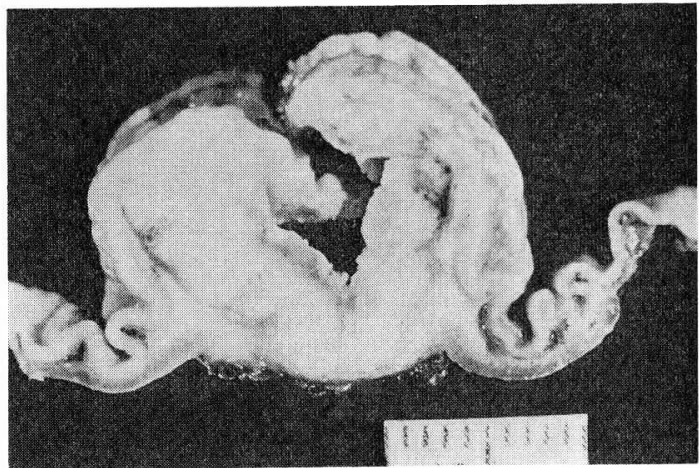

図 9 症例 6 の胃平滑筋肉腫 $(\times 3.5)$

腫瘍は粘膜下にあり中心部が壊死により粘膜に開口している。

いと思われる。

細胞塊として永離する時は相互封人のごとき細胞配例 を示すが, 細胞間隙は広く, 細胞間橋はなく, 上皮性細 胞のそれとは異なる。

横紋筋肉腫 : 平滑笳肉腫にくらべて, その剝離細胞は 多彩であり、しかもその組織学的型によりかなり異なる.

従来横紋筋肉腫は 1) 多形性型 Pleomorphic type 2) 胎児性型 embryonal type (Stobbe \& Dargeon) 3) 胞巣状型 alveolar type に大別され，胎児性型の亜型と してふぶどう状型 botryoid type (Horn) があるといわ れているので $, 6,8,9,13,14,17)$ ，それぞれの組織型に整理し 


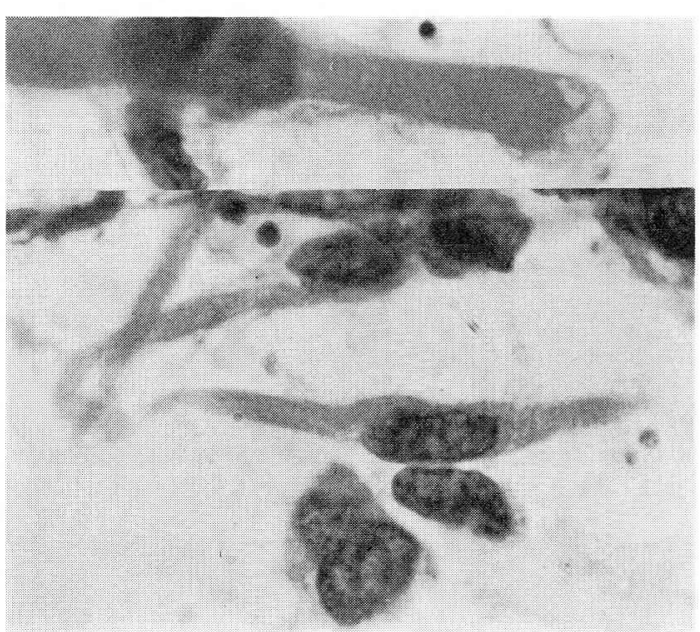

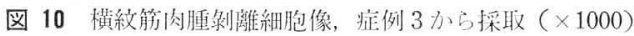

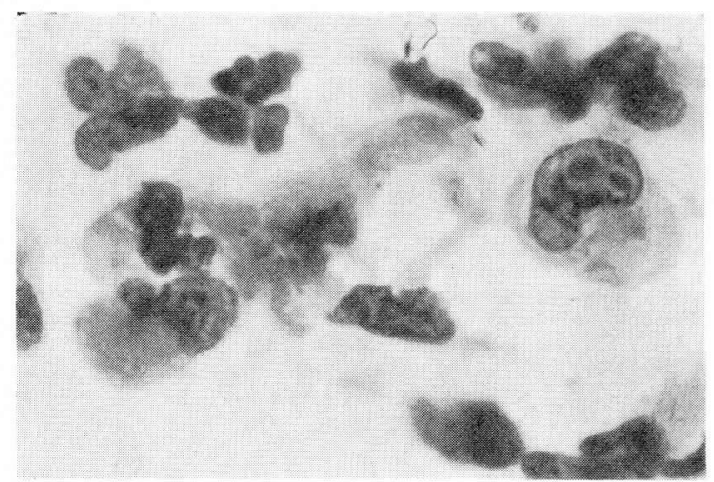

図 11 横紋筋肉腫剝離細胞像, 症例 3 力ら採取横紋筋細胞 $(\times 1000)$

て剝離細胞像を記載したい.

多形性型である症例 3 はその名のごとく構成細胞は最 も多彩であった。この標本は卵巣に発生した悪性奇型腫 のかなりの部分を占める横紋筋肉腫である。 その剝離細 胞は線維状の細胞と円型細胞の混合集団であり前者には 典型的な縦紋と横紋がみられ，核は細胞のほぼ中央に位 置している（図 10）。これに対し, やや大型な円型細胞 で，多少偏在した核，そして一般に大型な単在性の核小 体を示す細胞であり，その細胞質に強くエオジンに染る 顆粒状物質の充満した細胞が認められた. 前記の線維状 細胞がリボンならば，その間に赤いビーズが散在するか の感じがあった。後者は横紋筋芽細胞, Rhabdomyo blast (Enzinger and Shiraki)1)であろらと, 推定され た. 多榜細胞，特に $4 \sim 5$ 個あるいはそれ以上に縦に連 珠状に配例した多核細胞，ラケット状の細胞，小型紡錘 状細胞等も混在し，きわめて多彩であった（図 10, 11, 12)。その組織像も図 13 に示寸ごとく, 多彩な組織像で

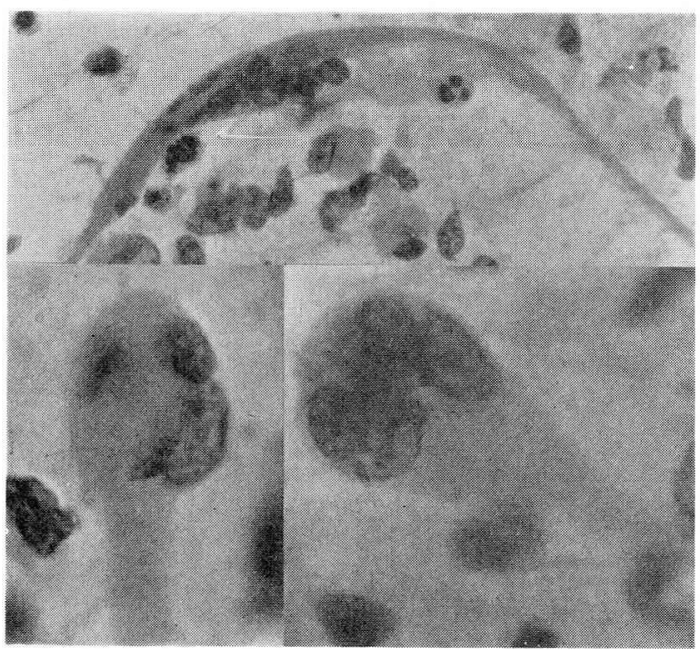

図 12 種々の横紋觔肉腫細胞, 拉例 3 から採取 $(\times 200, \times 1000)$

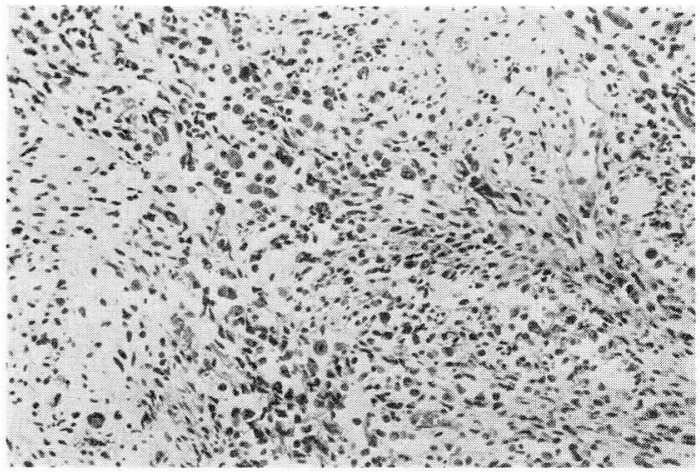

図 13 症例 3 の横紋筋肉腫組織像, 多型性型 $(\times 100)$

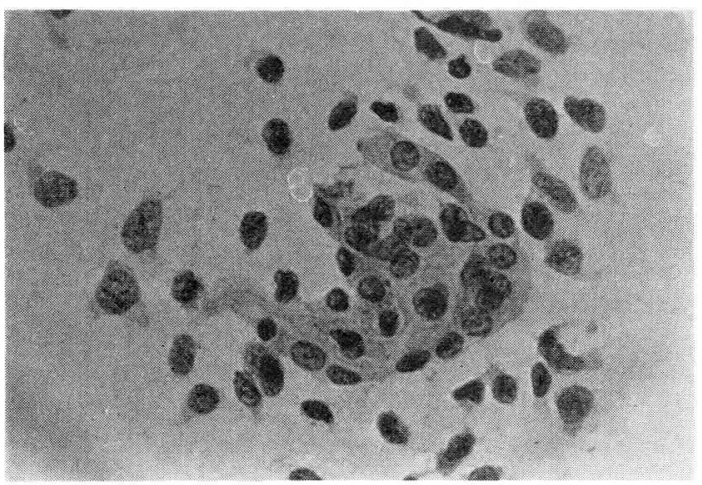

図 14 症例 2 から採取した横絞筋肉腫細胞 $(\times 400)$

あった、胎児型の症例 2 は, あまり特徵のない小型紡錘 細胞に混じって図 14，15 そみられるような一部横紋が 僅かに見える大型の横紋筋肉腫細胞が少数混在し, 横紋 筋芽細胞はみられなかった（図 16).

症例 1 はぶどら状型 (Botryoid 型) の肉腫からキモト 


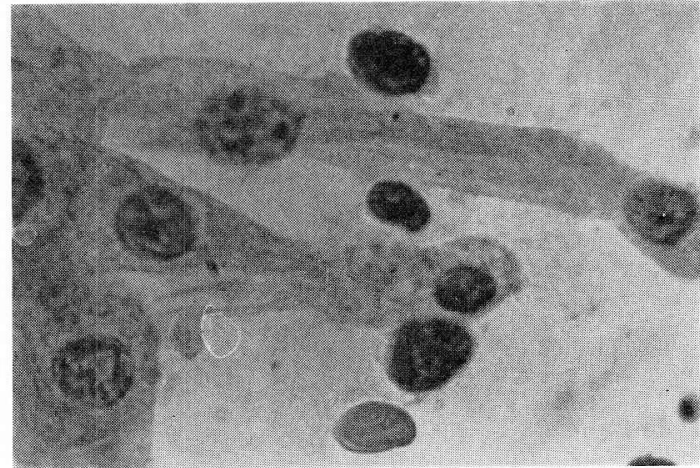

図 15 症例 2 から採取した横紋筋肉腫細胞（×1000）

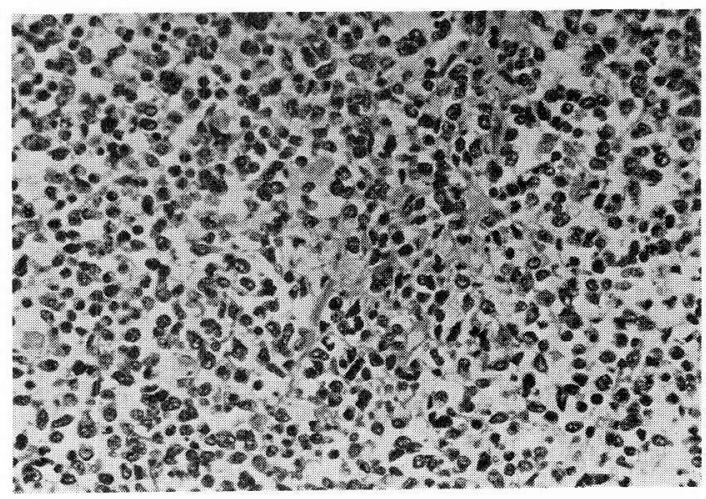

図 16 症例 2 の胎坚型横紋觔肉腫組織像 $(\times 100)$

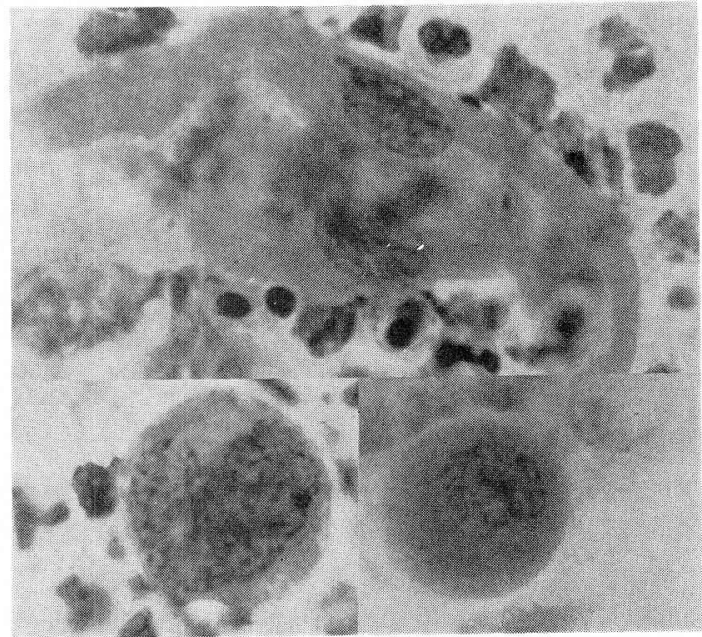

図 17 症例 1 の膀胱蒾キモトリプシン洗滌することにより 得られた横紋筋肉腫細胞 (ぶどう状型) $(\times 1000)$

リプシン洗滌により細胞を得たが，炎症がかなり強く， その剝離細胞数は必ずしも多くない，しかし明らかに横 紋筋肉腫細胞を思わせる大型の線維状細胞が出現し，こ れに加えて少数の小型異型細胞がみられた。図 17,18 , 組織像では明らかに図 19 に示すごとく明確な横紋がみ

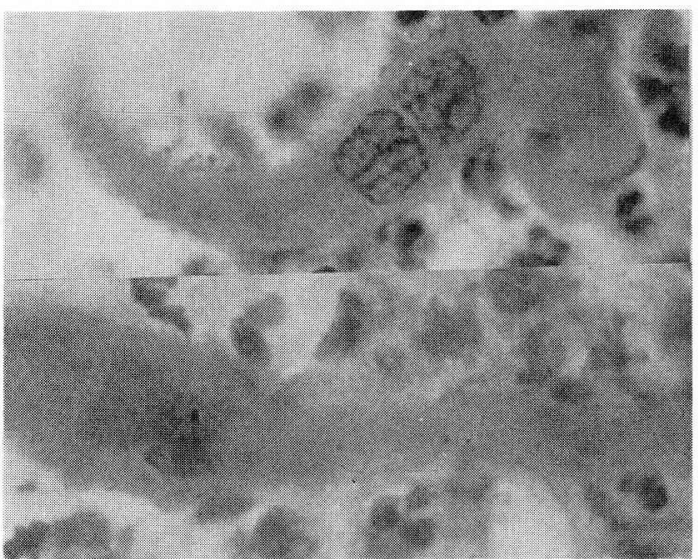

図 18 症例 1 より得られた横紋筋肉腫細胞 $(\times 1000)$

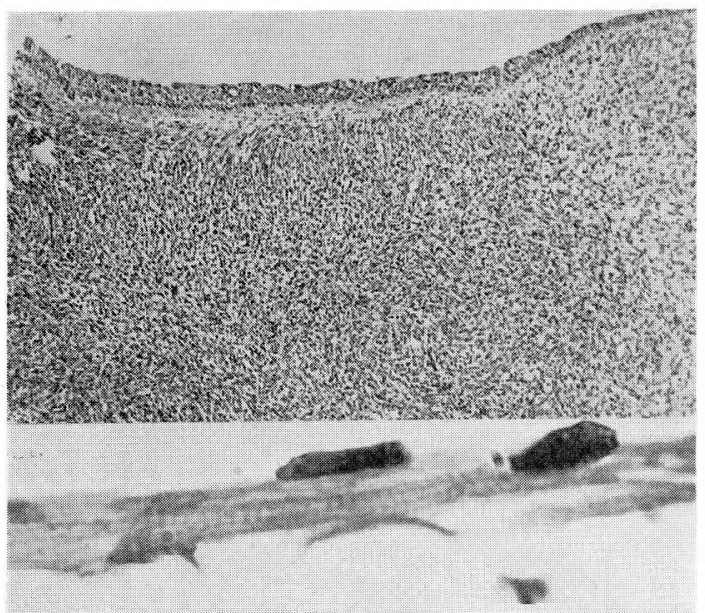

図 19 症例 1 の横紋筋肉腫組織像, ぶどう状型 $(\times 40, \times 400)$

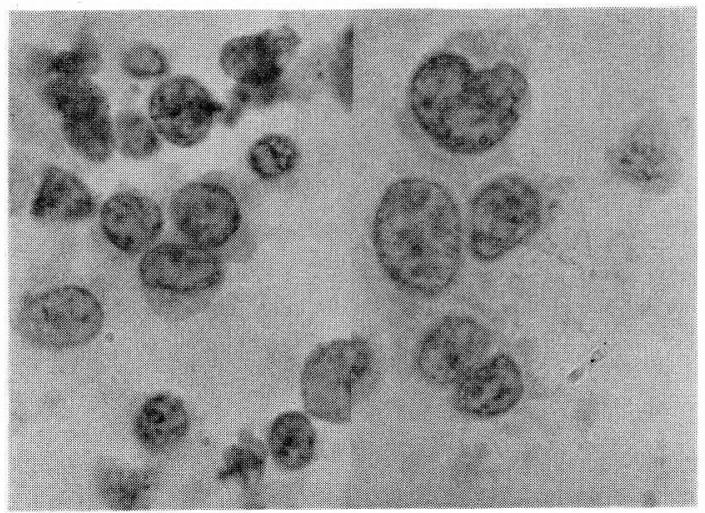

図 20 症例 4 の剝離細胞像, 粉化横紋筋肉腫 $(\times 1000)$

られたが，剝離細胞では変性のため，あまり明確ではな かった。

症例 4 はきわめて末分化型なるため，小型円型の異型 細胞がみられるのみで, あまり特徽的所見は少なく, 細 


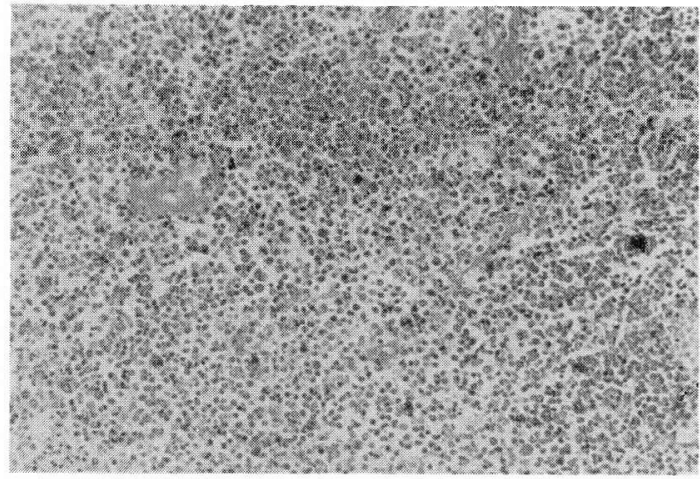

図 21 症例 4 の横紋筋肉䏦組織像 $(\times 100)$

網肉腫細胞を思わせる形態を示した。線維状の細胞は全 く認められなかった（図20，21）。

\section{考察}

平滑笳肉腫の悪性度は一般に低く, 特に消化器の平滑 筋肉腫の大部分は予後のよいものとされている. Penn$\mathrm{er}^{12)}$ の報告した例は $5 \mathrm{~cm}$ 大の浸潤性の平滑筋肉腫が何 ら治凂せずに自然に退縮したといら。このような例は例 外としても一応原発巣さえ切除出来れば多くの予後はそ れほどに亜いとは云えず，したがってこの腫瘍を一律に 悪性として断定するのに若干の躊躇を感ずる。少なくと も“但し書き”が必要であろう。しかしこの事実は，逆 に他の悪性腫瘍細胞之の鑑別診断に大きな意義が生まれ て来る。

奇異なことに組織像においても，その浸潤発育性の所 見や細胞異型よりも，分裂像の出現頻度が，患者の予後

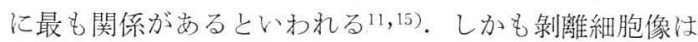
分化の度合により差があるが，一般に未分化になるにつ れて grotesque な多核細胞 (Koss) など出現すると $5,18)$ ，細胞の形態からは悪性が強いのではないかという 感覚的予測が生まれやすい，その反面正常筋線維や線維 細胞などは明らかに区別出来ることになる、剝離細胞所 見での悪性の度合も分裂細胞発見頻度により判定すべき であり，細胞異型は次に評価する必要があろう。

横紋筋肉腫の細胞像，特に多形性型のそれは多彩であ る. Horn \& Enterine ${ }^{6)}$ による，多形性型の組織標 本における横紋筋肉腫細胞は,

1. Broad elongated straplike or ribbonshaped cells.

2. Multiple nuclei arranged in random.

3. Large syncytial cells with multiple nuclei and bright eosinophilic cytoplasm.

4. Longitudinal striation or myofibrillen and less often cross striation.
と報告しているが，われわれの報告例の剝離細胞所見も 多くはこれに一致する. 最も特徴的な所見は細胞質にお ける横紋と, 特有な好酸性顆粒を含む横紋筋芽細胞であ り,この 2 つの所見が認められればまず横紋筋肉腫と断 定出来るであろら。しかし胎児性型は,より特徴が少ない 紡鍾細胞が大部分を占め少数の大型線維状の横紋筋細胞 が出現する可能性が高いからその同定は必ずしも容易で はない。平滑筋肉腫細胞を含めて, この笳原性肉腫細胞 のらち線維状の細胞は, 線維肉腫や神経性肉腫との区別 がむずかしいが，その細胞質の境界が線維肉腫では，より 不明瞭である。脂肪肉腫の分化型では類粘液細胞が出現 する.この場合は脂肪顆粒の細胞質内貯溜により区別し うる. 平滑筋肉腫細胞と横紋筋肉腫細胞との鑑別には PAS 染色が有用であるといわれる.グリコーゲンが横紋 筋肉腫にのみ存在するから両者の区別は容易であろう。

本編に示した細胞の大部分は直接塗抹標本における細 胞像であるが，通常の臨林において細胞を採取しうる細 胞は，この所見ほどに特徴的な所見が見出し難い場合も あろう。松田，建石の報告した子宮のぶどら状筋肉腫の 擦過細胞像 ${ }^{10)}$ もまた Hajdu \& Koss の示した筋肉腫細 胞も5), それほど明瞭に筋肉腫細胞の特徴を示している とは限らない，変性による細胞形態の修飾，殊に横紋の 不明瞭化沴断を迷わせる最大の原因となる.われわれ の症例でも組織では明らかに横紋が見えても膀胱洗湺 液中の剝離細胞では全く認められなかった例がある。 Beassler \& Voth ${ }^{2)}$ によると Botryoid 型の横紋筋肉腫 の電顕像において特有な層状構造を示寸核小体が観察さ れるといわれる. 将来電顕的検枽によらなくとも通常の 染色標本の観察により, この筋原性肉腫の特徵的な核内 構造が見出されるかもしれない.

\section{結語}

筋原性肉腫の 11 例（平滑筋肉腫 7, 横紋筋肉腫 4) の 剝離細胞像を記載した。 それぞれの腫瘍の分化の度合に よってその形態は異なるが, 平滑筋肉腫では, 特異な線 維状巨細胞, 不整形細胞, 連珠状核が配例する多核細胞 が出現するが，その細胞の種類は多くは単調である。こ れに対し横紋筋肉腫 (特に多形性型では) では分化した 横紋のみえる細胞から好エオジン性顆粒の充満した横紋 筋芽細胞等多彩な細胞像がみられた。

\section{Summary}

Touch smears and lavage specimens and corresponding histologic sections were examined from eleven patients with myogenic sarcomas (leiomyos- 
arcoma 7, rhabdomyosarcoma 4). And the morphological Characteristics of the tumor cells were erucidated.

In the specimens of the leiomyosarcomas, there were many cells to be fibrous and unstriated, irrespective of the differentiation of the tumor. However, giant cells, irregular or round cells and multinucleation were frequently observed in the tumors of the undifferentiated type. Multinuclei arranged along the longer axis of cell were most commonly observed in all the leiomyosarcmas examined.

On the contrary, the cellular morphology of the rhabdomyosarcoma varied considerablly each other according the histopathological types of the tumor. Among them the tumor of the pleomorphic type showed a plenty of cellular variety which was chiefly manifested by large fibrous cells presenting the transverse cross-striation and longitudinal fibrils in the cytoplasm and the myoblast with round shape and abundant granules of the eosinophilic nature in the cytoplasm. The other types of the tumor presented small spider-formed cells among which a small number of large fibrous cells with transverse cross-striation was found.

\section{文献}

1）安藤豊輔 : 蛋白融解酵素洗滌法による胃癌の剝離細胞学 的診断一特にX線透視選択的胃洗滌法による細胞採取方 法の改良, 同愛医誌, 4, 7 34, 1964.

2) Baessler, R. and Voth, D. : Pathologie und submikroskopische Morphologie des sogenannten sarcoma botryoides der grossen Gallengang. Z. Krebsforsch. 65, 44 55, 1962.

3) Berg, J. and McNeer, G. : Leiomyosarcoma of the stomach. A clinical and pathological study. Cancer 13,25 33, 1960 .
4) Enzinger, F.M. and Shiraki, M. : Alveolar rhabdomyosarcoma. Analysis of 100 cases Cancer 24, 18 31, 1969.

5) Hajdu, S.I. and Koss, L.G. : Cytologic diagnosis of metastatic myosarcomas. Acta Cytol. 13, 545 551, 1969.

6) Horn, R.C. and Enterline, H.J. : Rhabdomyosarcoma: A clinico-pathologic study and classification of 39 cases. Cancer 11, 181 199, 1958.

7）稻田俊雄 : 膀胱腫瘍の剝離細胞診, 日泌尿会誌, 58, $156 \sim 175,1967$.

8) Keyhani, A. and Booher, R.J. : Pleomorphic rhabdomyosarcoma. Cancer 22, 956 967, 1968.

9) Mackenzie, A.R. et al. : Myosarcomas of the bladder and prostate. Cancer 22, 833 844, 1968.

10）松田実, 建石龍平: Sarcoma botryoides $の$ 剝離細胞像 について, 日臨細会誌, 7, 78 82, 1968.

11) Lumb, G. : Smooth muscle tumors of the gastrointestinal tract and retroperitoneal tissue presenting as large cystic space. J. Path. \& Bact. 63, 139 147, 1951.

12) Penner, D.W. : Spontaneous regression of a case of myosarcoma. Cancer 6, 776 779, 1953.

13) 佐野量造：四肢軟部組織腫瘍の病理 (3)一横紋笳肉腫, 平 滑筋肉腫一臨整外， 6, 238 246, 1971.

14) Stout, A.P. : Rhabdomyosarcoma of the skeletal muscles. Ann. Surgery 123, 447 472, 1946.

15) stout, A.P. and Hill, W.T. : Leiomyosarcoma of the superficial soft tissue. Concer $11,844 \sim 854$, 1958.

16) Stout, A.P. Bizarre smooth muscle tumors of the stomach. Cancer 15, 400 409, 1962.

17) 高木文一：骨格筋の病変, 臨床組織病理学 (宮地編), 644 646, 杏林書院, 東京, 1968.

18）天神美夫他：子宮頸部肉腫の 1 例, 産婦人科の実際, 21 , $263 \sim 271,1972$.

19）山田喬: 剝離細胞診学, 文光堂, 東京, 1970. 